\title{
Transgression, Essentialism and Literary System: An Approach to the Viability of the Female Fantastic
}

\author{
Alfons Gregori \\ Adam Mickiewicz University, Poznan (Poland)
}

Follow this and additional works at: https://docs.lib.purdue.edu/clcweb

3

Part of the Comparative Literature Commons, and the Women's Studies Commons

Dedicated to the dissemination of scholarly and professional information, Purdue University Press selects, develops, and distributes quality resources in several key subject areas for which its parent university is famous, including business, technology, health, veterinary medicine, and other selected disciplines in the humanities and sciences.

CLCWeb: Comparative Literature and Culture, the peer-reviewed, full-text, and open-access learned journal in the humanities and social sciences, publishes new scholarship following tenets of the discipline of comparative literature and the field of cultural studies designated as "comparative cultural studies." Publications in the journal are indexed in the Annual Bibliography of English Language and Literature (Chadwyck-Healey), the Arts and Humanities Citation Index (Thomson Reuters ISI), the Humanities Index (Wilson), Humanities International Complete (EBSCO), the International Bibliography of the Modern Language Association of America, and Scopus (Elsevier). The journal is affiliated with the Purdue University Press monograph series of Books in Comparative Cultural Studies. Contact: <clcweb@purdue.edu>

\section{Recommended Citation}

Gregori, Alfons. "Transgression, Essentialism and Literary System: An Approach to the Viability of the Female Fantastic." CLCWeb: Comparative Literature and Culture 22.4 (2020): <https://doi.org/10.7771/1481-4374.3691>

This text has been double-blind peer reviewed by $2+1$ experts in the field.

The above text, published by Purdue University Press @Purdue University, has been downloaded 0 times as of 03/14/ 21.

This document has been made available through Purdue e-Pubs, a service of the Purdue University Libraries. Please contact epubs@purdue.edu for additional information.

This is an Open Access journal. This means that it uses a funding model that does not charge readers or their institutions for access. Readers may freely read, download, copy, distribute, print, search, or link to the full texts of articles. This journal is covered under the CC BY-NC-ND license. 


\title{
PURDUE
}

UNIVERSITY PRESS <http://www.thepress.purdue.edu>

\section{CLCWeb: Comparative Literature and Culture}

ISSN 1481-4374 <http://docs.lib.purdue.edu/clcweb> Purdue University Press @Purdue University

CLCWeb: Comparative Literature and Culture, the peer-reviewed, full-text, and open-access learned journal in the humanities and social sciences, publishes new scholarship following tenets of the discipline of comparative literature and the field of cultural studies designated as "comparative cultural studies." In addition to the publication of articles, the journal publishes review articles of scholarly books and publishes research material in its Library Series. Publications in the journal are indexed in the Annual Bibliography of English Language and Literature (Chadwyck-Healey), the Arts and Humanities Citation Index (Thomson Reuters ISI), the Humanities Index (Wilson), Humanities International Complete (EBSCO), the International Bibliography of the Modern Language Association of America, and Scopus (Elsevier). The journal is affiliated with the Purdue University Press monograph series of Books in Comparative Cultural Studies. Contact: <clcweb@purdue.edu>

\author{
Volume 22 Issue 4 (December 2020) Article 3 \\ Alfons Gregori, \\ "Transgression, Essentialism and Literary System: \\ An Approach to the Viability of the Female Fantastic" \\ <http://docs.lib.purdue.edu/clcweb/vol22/iss4/3> \\ Contents of CLCWeb: Comparative Literature and Culture 22.4 (2020) \\ Special Issue New Perspectives on the Female Fantastic. Ed. David Roas and Patricia Garcia \\ <http://docs.lib.purdue.edu/clcweb/vol22/iss4/>
}

Abstract: The main aims of this article are firstly to find out whether the concept of "fantastic female" is a contradictory and ambiguous construct, and secondly to challenge the feasibility of applying it to literary studies. The matter of the existence of the "female fantastic" refers to the theoretical approaches made to undertake a double-edged task in the 1970s and 1980s: the conceptualization of a dual scheme establishing a female aesthetic opposed to the dominant patriarchy on the one hand, and on the other, the promotion of non-mimetic narrative modes as formulas for transgressing the patriarchal system. However, the crystallization of dichotomies built on essentialized terms collided with the transgressing function that some narrative fiction performs when occupying marginal positions within the literary system. The main conclusion is that textual features and narrative modes function in some way as devices for a reification of the female body in the cultural sphere. 


\section{Alfons GREGORI}

\section{Transgression, Essentialism and Literary System: An Approach to the Viability of the Female Fantastic}

\section{Introduction}

As the author of an article significantly titled "Contra el generolecto: una lectura crítica des del constructivismo" (Against Genderlect: A Critical Constructivist Account, 2007), my stance is clearly at odds with the characterization of any fraction of literature as "female" when dealing with language as the main factor of the analysis. For those not initiated in this sociolinguistic terminology, some explanation is needed here: "genderlect" belongs to the taxonomical implementation of the diastratic description of language, although it has also been applied to certain works on literary studies ${ }^{1}$. In this respect it has been used to refer to an ensemble of traits that would be typical of only one of the two heteronormative genders, that is, a variety of male or female types of language. In my disapproval of the term, I argued that the concept of genderlect materializes an essentialist viewpoint in the epistemological and methodological sociolinguistic study, or at least it tends towards an essentialism with gender attributes, especially if the use of the term is indiscriminate and scarcely reasoned (Gregori, "Contra el generolecto" 3683). In considering literature as a linguistic verbalization, an important task of scholars working in literary studies is to decide what are the relevant characteristics of the language used in the surveyed works and to examine how to distribute them when creating categories that might prove useful at an epistemological level.

The fantastic narrative mode has been one of the most interesting and fruitful creative fields for women since it began with supernatural Gothic fiction in Great Britain. Hitherto, few published academic works have satisfied two pertinent conditions: firstly, to be exclusively concerned with the use of language as a differentiating component in fantastic literature written by women; secondly, to rely on the paradigm of this narrative mode that has become not only the most widespread among scholars of the humanities, but the most precise and pertinent when dealing with the diversity of functions and effects involved in the divergent non-mimetic modes of literature. ${ }^{2}$ I make reference to David Roas' approach, which sums up various postulates by outstanding researchers on the fantastic narrative mode that have appeared in recent decades, ${ }^{3}$ thereby offering a psychologist's view based on the reception of the text within its sociocultural context. In the English translation of his work Behind the Frontiers of the Real ${ }^{4}$ (2018), Roas defines the fantastic as follows:

... the fantastic is built on the conflict that arises from the coexistence of the real and the impossible. The condition of impossibility of the fantastic phenomenon is established, in turn, based on the conception of the real that both characters and receivers share: the impossible is that which ... cannot be, that which is inconceivable (inexplicable) according to the said conception of the real. This also determines ... one of the basic conditions of the fantastic to work: the necessary setting of the events narrated in a world similar to our own; that is, built based on the idea that we share of the real extratextual world. (24)

This clear and succinct definition excludes texts that belong to other narrative modes of the unreal such as literary fairy-tales, surrealism, magical realism, science fiction and anticipation fiction in general from the very concept of the fantastic, which now encompasses or partly includes examples of fantasy, a more usual term whose starting point and most successful form has been the medievalizing of marvellous fiction. ${ }^{5}$ In fact, prominent scholars such as Lucie Armitt identify every mode or subgenre that slightly clashes with the mimetic pattern with fantasy, as shown in the following list that she quotes: "utopia, allegory, fable, myth, science fiction, the ghost story, space opera, travelogue,

${ }^{1}$ For instance, an early paper of the Catalan researcher Godayol i Nogué printed in 1994 or a present-day publication by Parkhurst (2018) on young adult literacy.

2 The work of Gloria Alpini, entitled The Female Fantastic: Evolution, Theories and the Poetics of Perversion (2009) - quite recent in any case -, deals with an extremely broad and lax understanding of the fantastic as a category.

${ }^{3}$ A short list might include the following names: Tzvetan Todorov, Irène Bessière, Ana María Barrenechea, Rosalba Cambra, and Rosemary Jackson.

${ }^{4}$ The original Spanish version was published in 2011 as Tras los límites de lo real.

${ }^{5}$ For a survey of the characteristics that distinguish the most relevant non-mimetic modes in literary studies even though they may also be applied in film, theatre, media, and comics studies- see the theoretical approach in my book La dimensión política de lo irreal (The Political Dimension of the Unreal) (Gregori 21-31). 
the Gothic, cyberpunk, magic realism; the list is not exhaustive, but it covers most of the modes of fiction discussed in this book as 'fantasy'" (Fantasy Fiction 1).

Taking this categorization into account, the present article presents a metacritical review of the study on the fantastic female, carried out using the tools resulting from the aforementioned theoretical perspectives, as well as an analysis of the entire process of its formulation and justification. The main aims of this work are firstly to find out if it is an ambiguous and contradictory construct, and secondly, to challenge the feasibility of applying the concept of "fantastic female" in literary studies. Since I believe that trying to cover every single contribution related to the subject in the following pages would be an impractical assignment, I will focus on some authors and works that are especially relevant to the discussion about the existence of a fantastic female, mainly because they were responsible for its emergence or because they coincided with this phenomenon.

\section{Is there a female literary language?}

First of all, we need to go back several decades to the intellectual and cultural revolution that led to the convergence of very distinct movements and schools of thought in post-war Europe, and the rise of the welfare state throughout the Western world: these include Marxism, psychoanalysis, feminism, existentialism, post-structuralism and deconstruction. They were the driving forces of the so-called "hermeneutics of suspicion" as its initiators or heirs. This research-based approach led to a radically different scenario in terms of the very understanding of literature and its overlapping within the social, political and cultural dimensions of the human being. In fact, to a greater or lesser extent, they contributed to the phenomenon that we know as the "linguistic turn", around which both the philosophy and anthropology of the twentieth century developed some of the ideas that have most effectively been articulated as discourses in the thought and political action of today's world. In this broad context, the question as to whether there is a "female fantasy" originally concerned the insight about language as a not so innocent instrument in the hands of writers and intellectuals, who were still authoritative figures in Western countries at that time.

The approaches of certain theorists of literary feminism who developed their hypotheses within the framework of the aforementioned revolution during the 1970s and 1980s must be taken into consideration. For expository reasons, I will distinguish between the controversial postulates emerging in Europe - and more specifically in France - and the American literary scholar Patricia Mayer Spacks, who represented a subtler but undoubtedly spirited advance in the feminist contemplation of the function of language in women's writing. The valuable thinking of Hélène Cixous and Luce Irigaray, among others, shaped a vision of female writing in conjunction with a ground-breaking comprehension of culture at every level: these were galvanized as reflections on the way of creating fiction, poetry, and essay by women from a positive and demanding point of view. Cixous (who was born 1937) presented it as l'écriture féminine (feminine writing). Their in-depth criticism of the Western patriarchal tradition, which Toril Moi described in her influential book Sexual/Textual Study Politics: Feminist Literary Theory (1985) and referring to Cixous in particular, as "an imaginary utopia" (100), constituted the premises attached to the European trend of the so-called "difference feminism". This subset of the overall movement for women's liberation has been repeatedly accused of being essentialist in its conception of humanity divided by gender categories. Thus, in her criticism of the system of binary oppositions that structured Western thought, Cixous established dichotomies that were compelling in the development of feminist literary criticism. Even though they are quite wellknown, it is worth recalling these in the following quotation, which was preceded in her essay "Sorties" (Sorties: Out and out: Attacks/Ways Out/Forays) by the scathing question "Where is she?":

Activity/Passivity

Sun/Moon

Culture/Nature

Day/Night

Father/Mother, Head/Heart Intelligible/Palpable

Logos/Pathos ... (Cixous and Clément 63) 
This binary system is an effective subjugation mechanism and a fearsome mechanism because, according to Cixous' argument, a terrible veneration for destruction, violence and, ultimately, death is active in the core of patriarchal thought (Cixous and Clément 63-129). However, the use that the French author makes of poetic language in an essay that was intended to be academic - a deliberate use as opposed to the preponderance of the rational logos and the most precise, dissecting logic in male domination - implies assuming somehow the distinction that she tries to present as pernicious to women. Certainly, it can be read as a kind of situationist strategy, that is, the appropriation of elements of the capitalist and patriarchal system itself to attack and undermine its power by inverting their original meaning in an ironical way. In doing so, situationists took advantage of the consequent parody's effect to ridicule their object of attack, and also to show the cleavages in the supposedly impeccable logic of patriarchy. This strategy was known as détournement (rerouting, hijacking) in French. Therefore, turning the lyrical language - that has been feminized as a powerless and harmless way of expression - into an effective weapon that creates a lethal discourse against male supremacy whilst simultaneously exhibiting the weakness and perversity of the latter, constitutes a luminous example of détournement. Moreover, poetic language allows the expression of ambiguities that open gaps in the phallogocentric structure of power, and this is in itself an alternative flow of thought in opposition to the patriarchal ordering and controlling tone. Be that as it may, the fact that this lyrical style is put into practice against a prototypically logical discourse reinforces the dichotomy between the two of them and materializes a distinction that apparently was not intended to be essentialist. Indeed, later and more incisive discussions on the subject did not alter the firm stances adopted by prominent feminist researchers, as Aneja summarizes: "Despite Cixous' caveats against the setting up of a rigid and binary structure of sexual attributes, feminist critics in the US and in England have grown increasingly wary of what they deem to be an essentializing praxis in Cixous' discourse. Among those who have most emphatically decried these tendencies are Gayatri Spivak, Toril Moi, and Ann Rosalind Jones, while others such as Robert Con Davis, Hélène Vivian Wenzel, Parveen Adams, Beverly Brown and Domna Stanton have tried to caution against the use of the female body as a central metaphor, and the subsequent biologism and essentialistic binarity within French 'écriture féminine'" $(60)$.

In the 1970s and 1980s, feminist intellectuals, activists, and writers committed themselves to worthy and non-explored aims resulting in ideological formulations or forms of protests that were not always unanimously accepted by contemporary or later critics and colleagues, or even those with whom they shared a left-wing orientation. On the one hand, a significant number of feminists continued the work of Cixous and criticized with determination the dichotomies historically established by the patriarchal system in order to discriminate against women. We must bear in mind that dichotomies of this sort were used to subjugate them to work tasks circumscribed to the domestic space and, in the best of cases, to a secondary social role. On the other hand, and in line with the discussion set out above, the feminist followers of Cixous participated in the conceptualization of a scheme of dualities. This process ended up establishing the fundamental features of a (supposedly) female aesthetic that aspired to overthrow the dominant patriarchy by means of a writing practice carried out by women authors. They remained strongly opposed to the patriarchal system and adopted textual features deemed female by the male critique; yet, they were judged positively within the framework of Cixous' écriture féminine because they were seeking to represent that female reality that was foreign to the dominant social and cultural discourse, despite being and parallel and complementary to "male" reality. Such literary works were intended to show the intrinsic value of the (female) forms of life that have been historically subordinated to the patriarchal order and also to denounce the submissive stance maintained by women while victims of social injustice. A large number of women authors have used a disturbing irruption of the fantastic to criticise the omnipresent patriarchy. In my opinion, the short story "En el hemisferio sur" (In the Southern Hemisphere), by the Spanish author Cristina Fernández Cubas, offers an uncanny and complex fantastic parody of this paradox in the context of the boom in women's writing of the late 1970s and early 1980s within the Spanish literary system (Gregori, La dimensión 258-273).

On the other hand, we can compare the less radical stances taken by the Anglo-Saxon countries to Cixous' postulates. In the U.S., the university professor Patricia Meyer Spacks (born in 1929) could be considered as someone who embodies this position. She published her influential book The Female Imagination in 1972, although the 1975 edition by Alfred Knopf in New York had probably a more echoed reception and reached a wider audience. 1975 was also the year that Cixous' list of dichotomies appeared in France, in her work "Sorties", which was integrated some months later into the cult collection of essays Le Rire de la Méduse et autres ironies (The Laugh of the Medusa and other 
ironies). Curiously enough, the English translation of "Sorties" was also published in the U.S.A. in 1975: it was the second part of the collection The Newly Born Woman, where the authorship was shared with Catherine Clément. However, Cixous does not mention Spacks in her book, nor does Spacks mention Cixous in that second edition. Most likely, they did not read each other's books that year, nor could there have been a mutual influence, but significantly their works emerged at the same time, each in its respective limited sphere at a time when there was no internet and when the world was less globalised than it is today.

Spacks was immersed in a critical tradition of an eminently masculine character that was ready to attempt a transgressive activity "from within the establishment". Indeed, her work is undeniably influenced by the powerful tradition of close-reading inherited from the New Criticism. We can observe that in her rather erudite interpretations, where careful attention is paid to what is expressed explicitly in the text. In addition, she dominates the analytical logic of that formalist movement, which is very far removed from Cixous' (almost) poetic prose. A meaningful question lies at the very axis of their research: while the French author embraced, as we have seen, the problematization of language, her American counterpart focused on the question of imagination. The concept that appears in the title of Spacks' book prevailed in some spheres. ${ }^{6}$ Nonetheless, her readings are obviously devoid of the southern ideological component of the New Criticism, which is deeply patriarchal, conservative and elitist; they are also devoid of the pure and absolute self-referentiality pursued by the disciples of this school of literary interpretation, because any authentic claim regarding the unbearable status of fiction female characters made by Spacks needed to be correlated to external, extraliterary facts and situations. Along these lines, several of the author's fundamental arguments coincide with those postulated by the French thinker and other European feminists. Thus, both coincide in declaring that female writing is not exclusive to women insofar as men can adopt it in their literary works - although women would employ this sort of artistic creation more, since they are far more engaged in fighting against the patriarchal status quo. Spacks focuses on the point of view taken by the different writers: "Of course it is by no means true that books by women necessarily differ vividly from books by men. Male writers are often 'sensitive' women frequently knowledgeable: the stereotypes don't apply. When writing novels, women deal with the problems that have always concerned novelists: relationships, personal identity, the interchange between individuals and society" (4). On the other hand, Cixous argues it in the following way: "Great care must be taken when working on feminine writing so as not to get trapped by names: a woman's signature on a piece of writing does not necessarily make it feminine. It might well be masculine writing, and conversely, the fact that a piece of writing is signed with a man's name does not in itself exclude femininity. It's rare, but you can sometimes find femininity in writing signed by men: it does happen" (52).

Another point of convergence between both authors lies in the conviction that, even with the different historical and social vicissitudes that have influenced the literary creation of both sexes, there is something like a "woman's point of view", a social conditioning throughout history caused by the subordination of women to man's order (Spacks 4). The opinion of the American scholar is fundamentally based on realist literature, that attached to the most plausible reality, the most true-tolife stories, which would be the so-called "literature of the self", as we shall confirm in the next quotation: "Women writing directly about their own lives in letters, journals, autobiographies, or indirectly in that concealed form of autobiography we call fiction, demonstrate that the experience of women has long been the same, that female likenesses are more fundamental than female differences" (Spacks 5). The notion of imagination in her view does not allude to any aspect outside the laws and logics that rule our world: in fact, it relates feminist commitment - because commitment it is - with a realist ambience, an everyday and naturalist display, essentially conforming to certain leftist perspectives that abhor what they called "escapism". Thus, in her book, she exposes the two different meanings of imagination that she is interested in, both going in practice beyond any nonmimetic intrusion into the text: 'Imagination' is a slippery term, designating a power that penetrates the inner meaning of reality but it is also a power that creates substitutes for reality" (6). Even if the latter could correspond to some sort of fantasy or the marvellous, these "substitutes for reality" actually happen to be rather virtual or potential worlds attached to our sense of reality, lacking in

${ }^{6}$ A problem with the interpretation of this title emerged when it was translated into Spanish as La imaginación femenina (1980). This translation proved problematic at an ideological level, since the English original had a biological nuance that the Spanish version turned into a cultural one. A more precise translation would have been "la imaginación de las mujeres" (the imagination of women). 
addition any substantial entity of their own. In contrast, in a text that appeared in $1976^{7}$ Cixous emphasised the unreal character of the work to be done for women's liberation, linking it to the concept of Imaginary order forged by Lacan, which incidentally can be identified with Jung's personal unconscious (Samuels 33): "Things are starting to be written, things that will constitute a feminine Imaginary, the site, that is, of identifications of an ego no longer given over to an image defined by the masculine $[\ldots]$, but rather inventing forms for women on the march, or as I prefer to fantasize, 'in flight' so that instead of lying down, women will go forward by leaps in search of themselves" (Cixous 52).

\section{Anne Richter, or championing the female fantastic}

The recently deceased Belgian writer Anne Richter (1939-2019) was much closer to Cixous' postulates than to those of Spacks, not only because of her convictions about the existence of a kind of literary language that is specific for women, but also because she focussed all her attention on non-mimetic literature, distancing herself from the realist concerns shown by the American researcher. ${ }^{8}$ At any rate, she made the female fantastic the central issue of her literary criticism. She was, on the other hand, a prolific anthologist, essayist, and fiction writer of non-mimetic narrative. She published several collections of short stories, i.e. Les Locataires (The Tenants, 1967), La Promenade du grand canal (The Ride Across the Grand Canal, 1995) or L'Ange hurleur (The Bawling Angel, 2008). She also wrote essays, notably dealing with two subjects: on the one hand, the Belgian writer of crime fiction George Simenon (i.e. Georges Simenon malgré lui [George Simenon despite himself, 1993], which won the literary award of the Parliament of the French-speaking Community]) and, on the other, the non-mimetic narrative modes. Most of her anthologies are related to the later, and the following are worth mentioning: L'Allemagne fantastique de Goethe à Meyrink (The German Fantastic from Goethe to Meyrink, 1973), Les contes fantastiques complets de Guy de Maupassant (The Complete Fantastic Short Stories by Guy de Maupassant, 1974) and Histoires fantastiques de doubles et de miroirs (Fantastic Stories with Doubles and Mirrors, 1981). In 2003 she received the Medallion as a Chevalier of the Order of Arts and Letters awarded by the French Republic.

As a scholar Richter claimed not only the existence and appropriateness of a female writing, but considered it to be the most advantageous channel for expressing a unique kind of non-mimetic literature due to the female connection with the irrational:

They [women] regenerate the world, restoring its burden of silence and night, as well as finding again the virtue of secret, pity, and madness; they wisely assess the scale of the unutterable.

For women (they should never forget it) master the art of expressing themselves differently. They enjoy the privilege of thinking in a way different from reasoning: using their own body, their instincts, their memories, or that imponderable which we commonly call the soul... Whereas the female fantastic established itself in an outstanding position, it cannot be explained at any moment or any price, because it stands on this side of the world of logical explanations (or beyond, this is still an open point). That is not due to its capriciousness or arbitrariness, but because it belongs to a reality different from that of the analytical deduction. (Le fantastique 9-10)

In this regard, she was the author of a fundamental anthology edited consecutively in two different editions: the first was published in 1977, shortly after the analysed works by Cixous and Spacks, under the title Le fantastique féminin: d'Anne Radcliffe à nos jours (The Female Fantastic: from Anne Radcliffe to the Present Day); the second, entitled Le fantastique féminin: d'Anne Radcliffe à Patricia Highsmith (The Female Fantastic: from Anne Radcliffe to Patricia Highsmith) and published in 1995, included an extended range of authors from different periods, although none later than the 1970 s. The 1977 edition consisted of 25 texts, while the second one contained 31. In addition, Til Brugman - the only Dutch author -, Mary Elizabeth Counselman, Anna Seghers, and the American writer Hortense Calisher were removed from the selection; what's more, Richter's self-chosen work was replaced: "A Plant's Sleep" instead of the initial "The Big Beast". The only writers to have two selected short stories in the definitive edition - the rest have only one - are both from the American continent: Edith Wharton and Silvina Ocampo.

7 Provocatively entitled "Le Sexe ou la tête?" (Sex or the head?), it originally appeared in French as the transcription of a conversation between her and the editors of the publication (Cixous 41).

${ }^{8}$ Certainly, the reference to Jung made above is not unwarranted in regard to Richter, as it we will see in this section of the chapter. 
In both editions of Le fantastique féminin and further essays, Richter adheres to a radical version of "difference feminism", making it evident in sentences such as the following: "... there is a way of life and thinking that is typically female..." (Le fantastique 10), or "men and women dream this way, in opposite directions" (Le fantastique 25). She does not even conceal her total disrespect for the former egalitarian feminist movement that achieved basic rights and fundamental freedoms for women during its first-wave period. Thus, when trying to present Virginia Woolf as a first-class precedent of the difference feminism, the Belgian researcher asserts: "This was the answer of a talented woman to the feminism that was then arising. Avoiding the seductive trap of 'equality' laid by the supporters of female emancipation, she [Woolf] sets against it a femininity, assuming its difference, gazing at itself as a positive and original action..." (Richter, Le fantastique 15). ${ }^{9}$

There are two significant traits of Richter's anthologies that can get considerably divergent appraisals when conducted from an academic point of view; interestingly enough, both are presumably motivated by the fact that the author is Belgian. On the one hand, the anthology implies an impressive effort for gathering the most diverse origins and languages from Europe and America. ${ }^{10}$ Like most of the literary systems developing on the periphery of a durable and powerful cultural focus, France in this case, the Belgian literary system tends to be more open to foreign influences and to resist in a lower degree the ascendancy of other literary models. In fact, Richter's book recalls the most significant anthology of fantastic literature, which is the Antología de la literatura fantástica (1940) compiled by Jorge Luis Borges, Adolfo Bioy Casares and Silvina Ocampo, not only because Argentina was on the periphery of the Western literary systems - to which many Argentinean authors felt close - when this book was edited, but because of their acceptance of all sort of literary expressions dealing with the supernatural and from many countries. Similarly, Richter was an intellectual who was personally concerned with works written in other languages because of her membership of the PEN Club and the International Association of Literary Critics.

On the other hand, the second type of diversity mentioned above is clearly disappointing, for she did not take into account two works printed in Paris in the 1970s, several years before the appearance of Le fantastique féminine: Todorov's Introduction à la literature fantastique (1970), a seminal and influential study that systematized a structuralist approach to the fantastic, ${ }^{11}$ and Le Récit fantastique: la poétique de l'incertain (Fantastic narrative: the poetics of the uncertain, 1974), by Irène Bessière, which was a solid, learned and reasonable reply to the former work from a cultural and historical perspective. Both define the fantastic in similar ways, but in her anthology, Richter decided to apply a broader and more popular understanding of the term "fantastic", matching, it would seem, the notion of this term that traditionally prevailed in Belgium. ${ }^{12}$ Probably due to her being a researcher grown and educated in this country, Richter's conception of the fantastic moves beyond the Anglo-Saxon sources of the Gothic and ghost stories and differs from the academic approach presented by Todorov or Bessière. The peculiarity of Belgium in this respect is the existence of a deeply rooted tradition of non-mimetic literature which has given rise to a literary trend considered characteristic of Belgian writers, although it embraces a wide range of modes, from the strictest fantastic to variants ascribed to the marvellous and to surrealism.

To assert nowadays that the writing of the supernatural is at the heart of Belgian literature and that this has been its relevant trait since its birth is to state the obvious. This literary seam crosses the history of Belgian literature like a guiding thread... The impressive flowering of the non-mimetic literature made critics conclude that the Belgian authors have a natural - almost innate - propensity for the supernatural, and that this sort of writing, designated "the Belgian School of the Bizarre" (École belge de l'étrange) since the 70s, constitutes an autonomous trend by means of which the singularity of Belgian literature written in French manifests itself, as announced by Edmond Picard in 1887. (Bizek-Tatara 7)

That could explain the reason why the anthologies compiled by Richter, as well as her academic and popularizing works among non-specialists, seem excessively tolerant in this regard, including formulas that decidedly escape from what was gradually agreed to be fantastic within academic spheres.

${ }^{9}$ Richter uses Woolf's praise of androgyny in the field of artistic creation as a way to reject the act of writing literature mimetically as men do (Le fantastique 15). However, that is in direct conflict with her own critical conception of the classical fantastic as a "hybrid art" (Richter, Le fantastique 11).

${ }^{10}$ Campbell Pread's selected short story, "The Bunyip", is the Australian exception that proves the rule.

${ }^{11}$ It was published in English five years later as The Fantastic: A Structural Approach to a Literary Genre.

${ }^{12}$ She maintains a good relationship with a group of Belgian writers of non-mimetic fiction, who met quite often to share their creative experiences and critic opinions: this group included Jean Muno, Georges Thinès, Jean-Baptiste Baronian among others. 
Hence, the selected texts include such a variety of non-mimetic examples that it would be a mistake today to designate the whole as "fantastic literature". Actually, a few short stories even depart from the non-mimetic, standing in the blurred field of the uncanny or the unusual. For this category fits the lyric realism of Virginia Woolf's "Solid Objects", belonging to her collection A Haunted House and Other Short Stories (1944), which is depicted by Richter herself as "daydreaming on the surprising metamorphoses of the real" (Le fantastique 206). The same may be said about "Les Rumeurs nocturnes" (Night Rumours), by the Belgian writer Marie Gevers, and about Marina Tsvetaeva's short story "The Devil", which - besides being partially autobiographical - is presented by the anthologist as the description of a little girl's ludic activity that is purely imaginary (Le fantastique 296). Among the fantastic typical of the $19^{\text {th }}$ century and the beginning of the $20^{\text {th }}$ century, designated as "classical fantastic", 13 we find works written by Anglo-Saxon authors: Vernon Lee's "A Wicked Voice", Emilia Pardo Bazán's "The Talisman", Edith Wharton's "The Pomegranate Seed" (translated as "L'Appel" [The Calling]) and "The Lady's Maid's Bell", Campbell Pread's "Le Bunyip" and "The Blue Limousine" by Ann Bridge. Regarding the contemporary fantastic, several short stories are closely related to it, such as for instance, Ivonne Escoula's "In the Ancient Future" and "The Animal" by Nina Cassian. Marie-Thérèse Bodart's "The Window" and Elsa Morante's "The Man with Glasses" are also part of the fantastic. However, other stories belong to the uncertain space of terror and the extraordinary uncanny, and these include Marie-Louise Kaschnitz's "A Noon Hour in Mid-June" and Daphné du Maurier's "The Birds". On the other hand, a few texts belong to the marvellous, such as Jeanne-Marie Le Prince de Beaumont's "Beauty and the Beast", George Sand's "The Big-eyed Fairy", and - as an example of Christian marvellous with an eerie shade - "The Fall" by Armonía Somers. Finally, the imagery of avant-garde trends and the atmospheres of the absurd distinctly influence such grotesque stories as "The Snail-Watcher" by Patricia Highsmith.

The diversity of modes or subgenres, approaches to the subject, tones and fictional configurations that appear in Richter's anthologies destabilize her assumption that the female fantastic (or nonmimetic fiction) differs from the masculine one. She is aware of this problem since she confirms the "masculinity" of the classical fantastic employed in the short stories selected in her anthology: "The first impression is that only the contemporary fantastic is really female and that, therefore, the former reveals the eternal woman more than any other" (Richter, Le fantastique 11). The point is that the Belgian critic does not offer a contrasting second impression following on from that first impression from the quotation, but she justifies and corroborates the assertion contained in the quotation: "Viewed from this angle, and pleasant though it may be, the fantastic written by Ann Radcliffe, Vernon Lee, or Emilia Pardo Bazán, for instance, immediately reveals its artifices. It could certainly be a masculine work; it amounts to some kind of asexual art, or rather a borrowed literature" (Richter, Le fantastique 11).

Her insistence on the idea of "revelation" indicates the strong link, the complete unity established by Richter between the female essence and authenticity, associating the classical fantastic with terms like "pretence" (faux-semblants), "in disguise" (déguisée), "in make-up" (fardée), "forced vision" (vision forcée), "false, wrong" (fausse) (Le fantastique 11-13). ${ }^{14}$ This resemblance is confirmed in a short survey that was published in 2017, two years before her death. In this essay Richter provides her concluding conception on female fantastic writing, drawing on fragments and ideas from previous works, but focusing on the figure of the female writer, as its title indicates: Les écrivains fantastiques féminins et la métamorphose (The Female Writers of the Fantastic and the Metamorphose). She tries to offer evidence of the female fantastic by analysing non-mimetic literary works whose main motif is metamorphosis. According to the Belgian critic, the best examples of her conception of the (female) fantastic emerge in stories presenting a protagonist who undergoes some kind of fusion with the nonhuman. This leads the author to assert that the topic or motif of the metamorphosis illustrates at best the virtues of her female fantastic. When arguing her points, Richter appeals insistently to Jung's postulates. ${ }^{15}$ In doing so, she adopts the discourse of both the psychoanalytical and structuralist analysis of myths in literature. Furthermore, she manages to converge this with ecofeminism,

${ }^{13}$ Richter herself distinguishes between classical and contemporary fantastic, revealing that she was attentive to the developing theories on this narrative mode at that time. She calls them respectively "fantastique traditionnel" and "fantastique moderne".

${ }^{14}$ She even considers the virility attached to this category as some kind of evil due to its "essential dishonesty" or "bad intentions" (mauvaise fois) (Richter, Le fantastique 11).

${ }^{15}$ She even suggests a certain influence of this intellectual figure over the writers of female fantastic: "It is not due to chance that the first real female storytellers of the fantastic were contemporaries of the psychoanalyst Carl Gustav Jung, who established 'the psychology of the innermost depths' (1875-1961)" (Les écrivains 16). 
reaffirming the essentialist oneness between women and nature that is rather characteristic of difference feminism. Likewise, she reinforces her main thesis in relation to non-mimetic fiction: its masculine mode, the classical fantastic, is always somewhat affected, mechanical and leaning towards unlikelihood. In my opinion, Richter simplifies a complex and intricate panorama regarding literature, politics, religion and culture from the second half of the $18^{\text {th }}$ century up to the years before the First World War in the $20^{\text {th }}$ century. She ignores or skirts round the following points: "when Western democracies progressed by limiting institutional power in order to allow more individual freedom for their citizens, the fantastic narrative mode flourished as a site of conflicts in which the individual's vulnerability and insecurity were increased. It was the literary mirror image of a different kind of defencelessness with regard to the one reigning in preindustrial times. It was a vulnerability that was rather connected with fragmentation in Western societies, where the very concept of epistemological legitimacy was gradually eroded, and public powers were clearly segmented" (Gregori, "Crossing Impossible Boundaries?" 126).

\section{Another way out? Transgression through modes}

During the times that coincided with the emergence of female writing and its correlate in the fantastic mode, a group of feminist researchers in literary studies engaged in disrupting the patriarchal system - at least to the extent of the sector acting on the side of difference feminism - prompting the use of non-mimetic genres as a form of transgression. On the basis of the analogy of "strong" and "weak" modes, which refer to a central or marginal position in the literary system, respectively, theses modes represented the power relations in society, with women being the "weak sex" against the discriminatory norms that have been imposed by male authorities throughout history. A sign of rebellion would be, therefore, to adopt a "weak" fiction mode in order to contest the strong genres that were hegemonic in the male-built canon. Two factors contributed to this strategy: The increasingly louder claims for the removal of the hierarchies established between high and low culture, and the globalisation of different expressions of popular culture around the Western world. According to this notion, the main literary tool for conceiving a liberating women's point of view was no longer the type of language used by the writers but the type of text of a narrative mode applied in their fiction works.

In the Anglo-Saxon world during the late 1970s and early 1980s when the fantastic tradition was quite relevant at all levels and even present in the literary canon, a group of scholars began an academic discussion on the role of non-mimetic literature as a mechanism of ideological confrontation with the patriarchy and capitalism as repressive regimes. In this agitated context, Rosemary Jackson was one of the researchers who applied ideological readings to fantastic literature, but her bibliographical contribution to the study of non-mimetic literature set her apart from the rest. Despite its misleading title, Fantasy: The Literature of Subversion (1981) is a must for those wishing to delve into fantastic theory. Jackson assumed Todorov's taxonomical legacy from a critical point of view, being empowered moreover by the analytic tools of feminism, (post)Marxism, as well as Freudian and Lacanian psychoanalysis. Broadly speaking, she used the poststructuralist approach that was sometimes called "French Theory", so there was a connexion between Jackson's intellectual references and Cixous' ideas. That is probably why the French thinker is quoted more than once in the former's book. Specifically, Jackson concluded that in fantastic fiction - but not at all in the fantasy literature that we label as medievalizing marvellous - the reader perceives a desire for something that is excluded from the cultural order, something opposed to capitalism and the dominant patriarchal system (176). The truth is that Jackson points out that the fantastic literature she refers to in such terms is rather a structural category than a thematic one (which would arise from the mere presence of supernatural elements) (175), reinforcing her debt to Todorov. Notwithstanding this, the structural dimension of the subversive potential ascribed to the fantastic - as the literature of desire, according to Jackson's characterization of it - might be analysed in other non-mimetic modes, like sciencefiction, or even in realist categories such as erotic or criminal fiction.

Lucie Armitt, an outstanding student of hers, became a significant scholar in her own right and a brilliant researcher. A decade after the publication of Fantasy: The Literature of Subversion, Armitt's main postulates were defended in her PhD thesis on the fantastic as transgression in contemporary women's fiction. In a manner very similar to Jackson, she argued that the ambiguity inherent in fantastic works, that is to say their unfinished character as texts with open readings, constitutes a very attractive feature in order to explore socio-political marginality and non-centrality (Armitt, Pushing Back the Limits 11). Furthermore, with a touch of British pragmatism, Armitt proposes the 
fantastic as an alternative to the "feminist utopia" that was presented in contemporary feminist science fiction studies: "Throughout [the dissertation] there is a presiding concern with the importance of paradox and ambivalence as a radical literary and political strategy. To this end, the concluding section sets this thesis within a feminist fantasy framework, arguing that the problematic dynamism of the fantastic offers far more transformative possibilities than the 'closed-system' of the feminist utopia" (Pushing Back the Limits). In fact, she accused the authors of these types of works of falling into the patriarchate's networks because of the sort of desire exposed in them, which would lack the necessary true political commitment (Armitt, Pushing Back the Limits 329-331). However, the option of turning the fantastic as such into a liberation weapon for women could also lean towards an essentialist approach. Indeed, even if the inherent features of this narrative mode are no longer something specifically present in the language of the text, they would be contained in the mode or genre in which such a work should be categorized. The fantastic mode or genre was to become a form embodying a female soul, a body to be recognized by its gendered features. If the ominous or the uncanny had to be the requirement for designating a fiction as fantastic according to a considerable number of specialists, then was the female deemed to be identified with restlessness, fear or panic? Did the supernatural have to become the perennial metaphor of feminist rights?

\section{Conclusions}

Following Richter's postulates, where the most ominous modality of fantastic fiction - particularly the classical fantastic - is a masculine construction, adulterated moreover with unlikely falsehoods from a perspective based on literary pragmatics, the female fantastic is based on the authenticity of the connection between women and the non-human world (the vegetable, mineral and animal worlds). The Belgian author not only presents arguments for the existence of a female fantastic endowed by her with another sort of non-mimetic fiction, but she provides an ideological interpretation that bestows a moral righteousness, a epistemological superiority on these narrative modes when written with a special orientation, the so-called "female fantastic". Her intention should be positively welcomed due to several interesting reflections in her essays on the distinction between the classical and the modern fantastic, pointing out the inherent negativity of the former and the potentially constructiveness and guiding capability of the latter. However, is the application of the female fantastic viable despite its ambiguity and the contradictions between the two positions presented in the article, the linguistic approach and (much more succinctly) the mode-based critical interpretation?

In my opinion there are two issues to consider here: the establishment of a "female aesthetics" seeks to distinguish certain textual features in female writing, whereas the tendency based on the transgressive narrative modes attempts to correlate types of texts with the feminist commitment of women writers. On the other hand, the answer to the questions posed above is not unique: it depends on an approach that avoids essentialisms and the meaning that is attributed to the adjective "female". Yet, in consonance with the contradictions that arise from the exposed antithetical positions, it appears indisputable than the concept of "fantastic female" is an ambiguous construct. As such, it lacks the precision and univocity that should characterize academic terms, and - unlike the concept of fantastic itself - no definition up to now has clarified its extent and specific features within the field of non-mimetic fiction. Weather no one might exclude the expression "fantastic female" from the casual speech or the arena of debate, its ambiguity makes inappropriate its very application to literary studies, where researchers already must wrestle with frequent foggy terms. In fact, the most logical and sensible conclusion is that both the linguistic approach to the female fantastic and its mode-based critical interpretation function in some way as devices of reification of the female body within the cultural sphere.

\section{Works cited}

Alpini, Gloria. The Female Fantastic: Evolution, Theories and the Poetics of Perversion. Aras Edizioni, 2009.

Aneja, Anu. "The Medusa's Slip: Hélène Cixous and the Underpinnings of Écriture Féminine." Hélène Cixous. Critical Impressions, edited by Lee A. Jacobus, and Regina Barreca, Gordon and Breach Publishers, 1999, pp. 58-75.

Armitt, Lucie. Fantasy Fiction: An Introduction. Continuum, 2005.

---. Pushing Back the Limits: The Fantastic as Transgression in Contemporary Women's Fiction. 1992. University of Warwick. PhD dissertation. 
Bizek-Tatara, Renata. "Préface". Au-delà du réel: écritures du surnaturel dans les lettres belges francophones (Beyond the real: writings of the supernatural in the Belgian francophone literature), edited by Renata BizekTatara. Wydawnictwo Uniwersytetu Marii Curie-Skłodowskiej, 2017, pp. 7-11.

Bessière, Irène. Le Récit fantastique: la poétique de l'incertain (Fantastic narrative: the poetics of the uncertain). Libraire Larousse, 1974.

Cixous, Hélène. "Castration or Decapitation?". Translated by Annette Kuhn. Signs, vol. 7, no. 1, 1981, pp. 41-55.

Cixous, Hélène, and Catherine Clément. The Newly Born Woman. Translated by Betsy Wing, University of Minnesota Press / Manchester University Press, 1986.

Godayol i Nogué, Maria Pilar. "L'home i la dona: dues cultures, dos llenguatges, dos estils?" (Man and Woman: two cultures, two languages, two styles). Actes del II Congrés Internacional sobre Traducció (Proceedings of the 2nd International Conference on Translation held in Bellaterra in April 1994), edited by Montserrat Bacardí, Universitat Autònoma de Barcelona, 1997, pp. 551-559.

Gregori, Alfons. "Contra el generolecto: Una lectura crítica desde el constructivismo" (Against Genderlect: A Critical Constructivist Account). Actas del VI Congreso de Lingüística General. Santiago de Compostela, 3-7 de mayo de 2004 (Proceedings of the $6^{\text {th }}$ Conference on General Linguistics held in Santiago de Compostela from May the $3^{\text {th }}$ to May the $7^{\text {th }} 2004$ ), edited by P. Cano López et al. Vol. III, Arco/Libros, 2007, pp. 3681-3689.

---. "Crossing Impossible Boundaries? Fantastic Narrative and Ideology." Exploring the Fantastic: Genre, Ideology, and Popular Culture, edited by Ina Batzke et al., Transcript, 2018, pp. 117-140.

---. La dimensión política de lo irreal: el componente ideológico en la narrativa fantástica española y catalana (The Political Dimension of the Unreal: Ideology in Spanish and Catalan Fantastic Narrative). Poznań: Wydawnictwo Naukowe UAM, 2015.

Jackson, Rosemary. Fantasy: The Literature of Subversion. 1981. Routledge, 1988.

Moi, Toril. Sexual / Textual Study Politics: Feminist Literary Theory. 1985. Routledge, 2002.

Parkhurst, Howard B. "Conversations in Male Genderlect in Young Adult Fiction: Their Effect on Reading Motivation". Theory and Practice In Language Studies, vol. 8, no. 1, 2018, pp. 1-8. doi.org/10.17507/tpls.0801.01.

Richter, Anne. Georges Simenon malgré lui (George Simenon despite himself). Bernard Gilson, 1993.

---. Histoires fantastiques de doubles et de miroirs (Fantastic Stories with Doubles and Mirrors). Librairie des Champs-Élysées, 1981.

---. L'Allemagne fantastique de Goethe à Meyrink (The German Fantastic from Goethe to Meyrink). Marabout, 1973.

---. L'Ange hurleur (The Bawling Angel). L'Âge d'Homme, 2008.

---. La Promenade du grand canal (The Ride Across the Grand Canal). Talus d'approche, 1995.

---. Le Fantastique féminin: d'Anne Radcliffe à nos jours (The female fantastic: from Anne Radcliffe to the present day). Marabout, 1977

---. Le Fantastique féminin: d'Anne Radcliffe à Patricia Highsmith (The female fantastic: from Anne Radcliffe to Patricia Highsmith). Complexe, 1995.

---. Les contes fantastiques complets de Guy de Maupassant (The Complete Fantastic Short Stories by Guy de Maupassant). Marabout, 1974

---. Les écrivains fantastiques féminins et la métamorphose (The female writers of the fantastic and the metamorphose). Académie Royale de Belgique, 2017.

---. Les Locataires (The Tenants). Pierre Belfond, 1967.

Roas, David. Behind the Frontiers of the Real: A Definition of the Fantastic. Palgrave Pivot, 2018. doi.org/10.1007/978-3-319-73733-1.

Samuels, Andrew. Jung and the Post-Jungians. Routledge, 1985.

Spacks, Patricia Meyer. The Female Imagination. Alfred A. Knopf, 1975.

Todorov, Tzvetan. The Fantastic: A Structural Approach to a Literary Genre. Translated by Richard Howard, Cornell University Press, 1975.

Woolf, Virginia. A Haunted House and Other Short Stories. Hogarth Press, 1944.

Author's profile: Alfons Gregori is an Associate Professor at the Adam Mickiewicz University in Poznan (Poland) where he is currently the Head of the Centre for Catalan Studies. He is the author of the book La dimensión politica de lo irreal: el componente ideológico en la narrativa fantástica española y catalana (2015). The books he has coedited include Discurso sobre fronteras - fronteras del discurso (2007), the three published volumes of "Literatury mniejsze" Europy romańskiej ["Minor literatures" in Romance Europe] (2012, 2015, 2017), and special issues in the academic journals Studia Romanica Posnaniensia and Brumal devoted to literature, cinema and terrorism or ideology in the fantastic. He has authored numerous academic articles and book chapters on fantastic literature, gender studies, contemporary popular music, and literary translation. He was the lead researcher for the grant project "The ideological element in fantastic literature" (2011-2015), financed by the Polish National Science Centre. He has been distinguished for his work promoting Catalan culture abroad and he was one of the winners of the 2017 IPECC award "Josep Maria Batista i Roca - Memorial Enric Garriga Trullols". Email: <alfons@amu.edu.pl> 